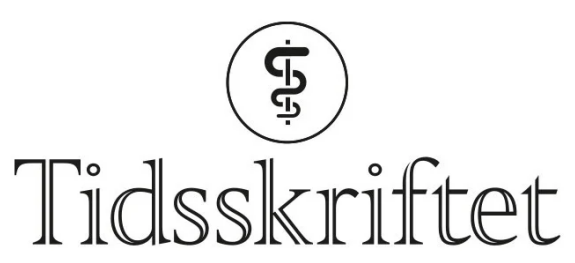

DEN NORSKE LEGEFORENING

\title{
Nevrokirurgi i stikkordformat
}

\author{
ANMELDELSER
}

TERJE SAEHLE

Sjeflege, Seksjon for menneskelig ytelse og utdanning

Luftfartstilsynet

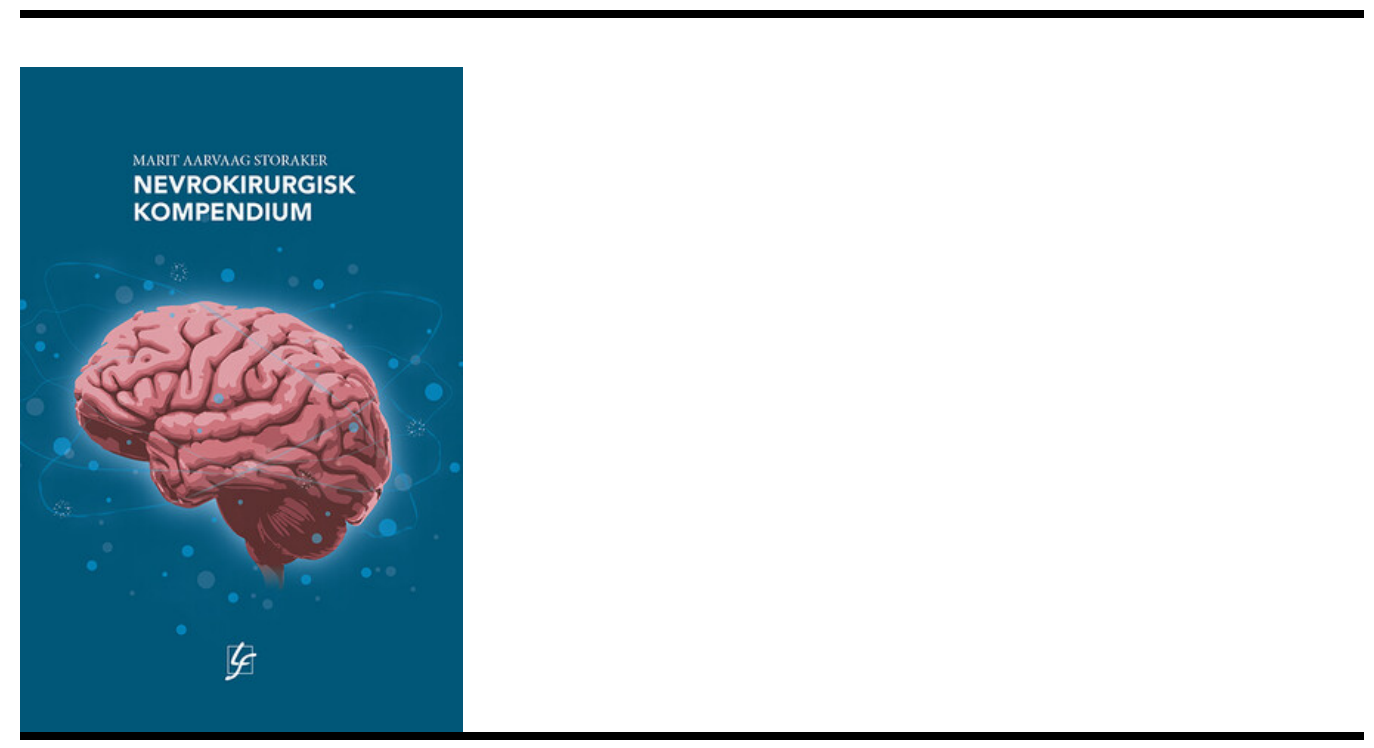

Marit Aarvaag Storaker

Nevrokirurgisk kompendium

200 s, tab, ill. Oslo: Legeforlaget, 2020. Pris NOK 525

ISBN 978-82-9293419-7

Nevrokirurgisk kompendium er en bok på 200 sider i et hendig A5-format som passer akkurat i lommen på legefrakken. Formålet er å bistå leger med en rask avklaring av nevrokirurgiske problemstillinger på vakt eller i en travel hverdag på sykehuset. De ulike kapitlene er presentert systematisk, med ulike fargekoder for hvert av hovedtemaene og en punktvis opplisting av fakta. Dette gjør boken lettlest, og man kan slå opp på ønsket tema på kort tid.

Kompendiet har i struktur og innhold mange likhetstrekk med undertegnedes eget kompendium i nevrokirurgi fra 2008, som inngår i kildelisten til Storaker (1) . Mange avsnitt er nesten identiske. Tiden har vært moden for en oppdatering, og Storaker har i 
tillegg valgt en layout og typografi som gjør håndboken både elegant og oversiktlig. Dessverre har forfatteren også videreført svakhetene som var årsaken til at jeg selv utarbeidet kompendiet for intern bruk på sykehuset og ikke kommersialiserte det for et bredere publikum.

Faglitteratur bør inneholde tydelige henvisninger til hvilke referanser de ulike punktene eller anbefalingene bygger på. Utover en opplisting av 18 generelle kilder på siste side inneholder boken ingen fortløpende referanser. Kildehenvisning som «Helsebiblioteket», «Helsedirektoratet» eller «UpToDate» er for upresist til at leseren har anledning til å granske bakgrunnsmaterialet.

En systematisk kvalitetssikring opp mot oppdaterte faglige kilder ville også bidratt til å luke ut enkelte faglige feil i boken. Det kunnes også tydeliggjøres hvilke anbefalinger som bygger på lokale prosedyrer, der disse skiller seg fra praksis på andre avdelinger eller internasjonal konsensus.

Storaker har inkludert mye interessant patofysiologi og epidemiologi. Det ville imidlertid vært mer hensiktsmessig å bruke denne plassen til praktiske prosedyrer og problemstillinger som man eksponeres for på vakt.

Kort oppsummert er Nevrokirurgisk kompendium lettlest og av en viss verdi for den beskrevne målgruppen. Samtidig har kompendiet i nåværende form enkelte mangler og potensielt misvisende detaljer. I disse dager finnes det mange internasjonalt anerkjente digitaliserte håndbøker som i større grad dekker problemstillinger på vakt eller operative prosedyrer. Mange vordende nevrokirurger vil trolig foretrekke disse, for eksempel Greenbergs Handbook of Neurosurgery i e-bokformat (2).

\section{LITTERATUR}

1. Sæhle T. Nevrokirurgisk kompendium for leger i spesialisering ved Rikshospitalet. Oslo: Rikshospitalet, 2008.

2. Greenberg MS. Handbook of Neurosurgery. New York, NY: Thieme, 2016.

Publisert: 16. august 2021. Tidsskr Nor Legeforen. DOI: 10.4045/tidsskr.21.0452

(C) Tidsskrift for Den norske legeforening 2023. Lastet ned fra tidsskriftet.no 26. april 2023. 